\title{
A global framework for management commentary disclosure?
}

\author{
Charlotte Villiers
}

University of Bristol

\begin{abstract}
Introduction
Qinancial statements alone do not sufficiently enable users to have a complete understanding of a particular business. The management commentary, which is a narrative report, therefore "comprises information provided outside financial statements that assists in the interpretation of a complete set of financial statements or improves users' ability to make efficient economic decisions". ${ }^{1}$ On this basis the International Accounting Standards Board (IASB) and partner standard-setters suggest that IAS 1 Presentation of Financial Statements should eventually include a requirement to prepare a management commentary. The IASB is therefore currently working on a project for developing an international framework for management commentary disclosure, with the intention of completing a guidance document during $2009 .^{2}$
\end{abstract}

The IASB seeks to create a best-practice approach corresponding with recent developments in various jurisdictions relating to narrative reporting. The UK's experience relating to the introduction of the enhanced business review requirements reveals some of the potential problems that must be overcome not only nationally but internationally also. In turn, the IASB's project is likely to impact upon the business review requirements recently introduced in the $\mathrm{UK}^{3}{ }^{3}$ The effectiveness of reporting under these new requirements may be measured against the IASB's approach to this issue. The work of the IASB is likely to shape judgments by managers and directors about what material to include in their business reports and it will also influence how the emerging reports are received by their users. The extent to which the current interpretations of the UK legislation match the IASB's thinking is relevant to the question of the prospect for successful harmonisation or convergence internationally of requirements for management commentary.

A leading commentator has suggested recently that convergence of international accounting standards generally reflects attempts to strengthen and spread a particular

1 Preface to International Financial Reporting Standards, para. 7.

2 See IASB, Management Commentary: A paper prepared for the LASB by staff of its partner standard-setters and others (hereafter Discussion Paper), October 2005. See also the IASB current projects webpage which provides details of the latest developments relating to the management commentary project.

3 Companies Act 2006, s. 417. 
version of global capitalism rather than genuinely to improve corporate governance. ${ }^{4}$ The management commentary agenda in its current form lends support to this claim.

This paper will explore, in part 1, why efforts are being made to converge accounting regulation internationally and, in part 2 , why the IASB considers extending those efforts by introducing guidance for a management commentary. In part 3, the paper will review existing management commentary requirements in other jurisdictions with particular focus on the new provisions introduced by the Companies Act 2006 in the UK. Part 4 will highlight key differences and similarities among the jurisdictional requirements. Part 5 will consider the IASB's principles-based approach to accounting standards and the management commentary. Part 6 will identify the intended users of management commentary and part 7 will consider the emphasis on managerial discretion which is related to the issue of directors' liability considered in part 8. Part 9 will explore the effects of the UK legislation to date and will suggest how implementation of this legislation might be influenced by the IASB's approach. Finally, the paper will conclude with remarks about the prospects for successful international convergence of management commentary regulation and the likely impact of these developments on international corporate governance more generally.

\section{International convergence of accounting rules}

According to Sir David Tweedie, then (and current) chair of the IASB, and Thomas R Seidenstein, director of operations of the International Accounting Standards Committee (IASC) Foundation, "the growing consensus around the benefits of International Financial Reporting Standards (IFRSs) reflects trends in an increasingly integrating global economy ... disparate national solutions to accounting's problems are not sufficient for an increasingly globalized market". ${ }^{5}$ In their article, Tweedie and Seidenstein observe the emergence of global capital markets in which it is possible for companies to list on major international exchanges outside their home jurisdictions giving them greater access to cheaper capital, and in which investors have gained new opportunities for diversification. ${ }^{6}$ The development of this globalised capital market gives rise to a need for international accounting standards with a consistently applied common financial language that will make comparable the financial results of companies operating in different jurisdictions. ${ }^{7}$ In this context, the reasons for standardisation appear to be reasonably straightforward. To continue with different accounting methodologies and reporting systems as markets are integrating would merely reduce comparability and might also mislead markets and capital allocation. ${ }^{8}$ Padoa-Scioppa suggests that such differences encourage a competition in laxity with countries lowering their standards "in a short-sighted attempt to attract listings or to appeal to special interests". ? The alternative of one set of standards should reduce compliance costs for multinational companies by avoiding the need to prepare different sets of accounts to satisfy different national requirements. ${ }^{10}$ One consistent international

4 L A Cunningham, “The SEC's global accounting vision: a realistic appraisal of a quixotic quest”, George Washington University Law School Public Law and Legal Theory Working Paper No. 401, 2008 (forthcoming in the North Carolina Law Review).

5 D Tweedie and T R Seidenstein., "Setting a global standard: the case for accounting convergence" (2005) 25 Northwestern Journal of International Law and Business 589, at 589-90.

6 Ibid., p. 590.

7 Ibid., p. 591.

8 T Padoa-Scioppa, "Comment", Financial Times, 19 May 2006, quoted in IASB, "Work on converging accounting standards must go on", 22 May 2006, at www.iasb.org/news/announcements+and+speeches (last accessed 8 July 2008).

9 Padoa-Scioppa, "Comment", n. 8 above.

10 Tweedie and Seidenstein, "Setting a global standard”, n. 5 above, p. 591. 
approach to accounting would also remove barriers to capital flows and would encourage more consistent accounting and auditing practices internationally which would also ease the tasks of regulators by reducing the need for them to understand different reporting requirements. ${ }^{11}$ The existence of a set of international standards that already had credibility in international capital markets would also benefit those jurisdictions without fully developed national standards by providing them with a ready made set of standards to meet the needs of their larger domestic companies. ${ }^{12}$

Since the IASC was founded in 1973 there has been significant progress in the work towards the development of a set of international accounting standards. Having started as a part-time standards-setter, the IASC was restructured and reconstituted in 2001, becoming the International Accounting Standards Board, a better-resourced, full-time professional standards-setter. ${ }^{13}$ The IASB states that its main objective is to construct a set of accounting standards based on the best standards around the world that constitute the highest denominator of financial reporting. ${ }^{14}$ In this way, convergence is based on the aims of improving financial reporting and of achieving consistency across capital markets. The IASC completed a core set of standards in 1998 which later received a qualified endorsement from the International Organization of Securities Regulators in 2000.

Since the IASB was inaugurated there has been significant success in establishing the IFRSs as the international basis of accounting. These standards are now fully accepted for overseas registrants by most of the world's stock exchanges and many countries have adopted the standards for unlisted companies and also as a model for their domestic standards. The European Union adopted a regulation in 2002 that requires publicly traded companies since 2005 to apply IFRSs for their consolidated accounts. ${ }^{15}$ Indeed, according to Jeff Willemain, of Deloitte, “the European Union's successful adoption of IFRS in 2005 spurred a sea-change in attitudes toward common standards of reporting. Today, more than 100 countries report under the international standards." 16 These include Australia, South Africa, China, Hong Kong and many Latin American countries, which also converged with or adopted IFRS as their national standards. ${ }^{17}$

In earlier times a major incentive for convergence rested with European companies seeking access to the strong US capital markets. ${ }^{18}$ The cost of their obligation to comply not only with their own national and European accounting regimes but also to reconcile their accounts with US GAAP (Generally Accepted Accounting Principles) requirements

11 Tweedie and Seidenstein, "Setting a global standard", n. 5 above, p. 591.

12 G Whittington, "The adoption of international accounting standards in the European Union" (2005) 14 European Accounting Review 127, at 129.

13 See D S Ruder, C T Canfield and H T Hollister, "Creation of world wide accounting standards: convergence and independence" (2005) 25 Northwestern Journal of International Law and Business 513. See also M J Hanson, "Becoming one: the SEC should join the world in adopting International Financial Reporting Standards" (2006) 28 Loyola LA International and Comparative Law Review 521, at 524-7.

14 Tweedie and Seidenstein, n. 5 above, p. 592, citing the objectives laid down in the IASC Foundation Constitution 5 of 2002 .

15 Council Regulation 1606/2002 of 19 July 2002 on the Application of International Standards, 2002 OJ L 243, 1, 1-4.

16 J Willemain, "Corporate reporting: trends and tensions in convergence" (2008) International Corporate Governance Network Yearbook, available on Deloitte website: http://www.deloitte.com (last accessed 5 August 2008). Jeff Willemain is global managing partner in the regulatory and risk section of Deloitte.

17 See IASPlus, Deloitte \& Touche, "News about international financial reporting", at www.iasplus.com cited by Tweedie and Seidenstein, "Setting a global standard", n. 5 above, p. 592.

18 S B Eaton, "Crisis and the consolidation of international accounting standards: Enron, the IASB, and America” (2005) 7 Business and Politics (article 4), available at http://bepress.com/bap (last accessed 8 July 2008), p. 4. 
would prohibit their entry into the American markets. A solution to this problem would be the development of a set of international standards applicable in all jurisdictions. For much of the time the US has shown greater reluctance to converge, with the Securities and Exchange Commission (SEC) making "effective use of the lure of US capital markets" and the Financial Accounting Standards Board (FASB) playing on the "commonly held view that American rules were best of breed" and advocating the adoption of US GAAP as the world's accounting standards as an alternative to international harmonisation. ${ }^{19}$ More recently the dramatic accounting scandals that have shocked America have instigated a change of attitude.

The Enron fiasco resulted in the US accounting authorities warming to principles-based standards ${ }^{20}$ and showing a greater willingness to work towards creation of international standards. ${ }^{21}$ The IASB and the FASB signed the Norwalk Agreement in October 2002 in which they agreed on a short-term project to eliminate minor differences between the international and the US standards, to address emerging issues jointly and to promote consistency in the pronouncements of both their interpretative committees. This agreement was updated in 2008 to include efforts towards convergence between US GAAP and IFRS. In November 2007, the SEC also demonstrated greater acceptance of the international standards by voting to scrap the reconciliation rule for foreign companies using IFRS to prepare their financial statements. ${ }^{22}$ Also, in 2008, the chair of the SEC, Christopher Cox, announced in a speech a proposed roadmap to include a schedule and appropriate milestones towards acceptance of IFRS. ${ }^{23}$

It might be considered from the above account that the US accounting regulators have compromised and shown a willingness to alter their position on accounting practice and regulation. However, it should also be remembered that since the origins of the IASC the US has played an influential role in its activities and those of its successor, not least because of funding and membership from US professional bodies and indirectly from the influence of the SEC on the International Organization of Securities Commissions (IOSCO) which, itself, has largely driven much of the IASC/IASB's activities. Thus some commentators have suggested that the IASB's work has been consistent with an "alignment internationally to an Anglo-American (becoming American) accounting, nested in related political economy".24 Nevertheless, some difficulties remain. First, in the US, the rules-based approach has favoured a belief in subjecting all to the same standards, and this is reinforced

19 Eaton, "Crisis", n. 18 above, p. 6. Some would argue that critics exploited the Enron debacle to complain that US GAAP was too detailed and had too many rules whilst the more general character and language of the IFRS were more appealing in competitive capital markets: see e.g. Cunningham, "SEC's global accounting vision", n. 4 above, p. 12.

20 See e.g. SEC, Study Report Pursuant to Section 108(d) of the Sarbanes-Oxley Act of 2002 (Washington: SEC 2003), recommending that "those involved in the standard setting process more consistently develop standards on a principles-based or objectives-oriented basis"; p. 5.

21 Eaton, "Crisis", note 18 above, p. 13.

22 See SEC, "Acceptance from foreign private issuers of financial statements prepared in accordance with IFRS without reconciliation to US GAAP", Release No. 33-8879, 21 December 2007, at www.sec.gov/rules/final/2007/33-8879.pdf (last accessed 8 July 2008).

23 See C Cox, "Remarks before US Chamber of Commerce", speech by SEC chair Christopher Cox, 18 April 2008, at www.sec.gov/news/speech/2008/spch041808cc.htm (last accessed 8 July 2008).

24 S Gallhofer and J Haslam, "Exploring social, political and economic dimensions of accounting in the global context: the International Accounting Standards Board and accounting disaggregation" (2007) 5 Socio-Economic Review 633-64, at 641. 
by Sarbanes-Oxley compliance. ${ }^{25}$ This contrasts with the principles-based approach. Secondly, there remains some irritation in the US about the EU's variation of the IAS 39, relating to hedge funds. ${ }^{26}$ Thirdly, there continues to exist considerable opposition from US chief finance officers to allowing companies to switch to IFRS or to allowing foreign companies to report against IFRS without reconciliation to GAAP. ${ }^{27}$ However, the reality of competition for global capital investments has pushed the SEC to nurture an enthusiasm for IFRS, noting that otherwise companies are likely to delist from the New York Stock Exchange and NASDAQ. ${ }^{28}$ Ultimately, as stated by Willemain, "taken together, the writing on the wall is clear: the debate over whether to move toward convergence of accounting standards has given way to a discussion of how to move to global standards". ${ }^{29}$

This significant progress in achieving wide-scale acceptance of the IFRS has encouraged the IASB to deepen its work and broaden the scope of its projects. One such move was to introduce a project on the possible development of an international standard or guidance for management commentary. The next section of this paper will consider the role of management commentary in financial reporting before going on to provide an overview of existing national requirements and practices.

\section{The IASB's vision of management commentary}

The IASB recognises that financial reporting is not sufficient to provide users with a full understanding of the company's business and position. Management commentary, in theory, plugs the gap by providing information that supplements and explains the financial reports. The aim is to provide a fair and balanced account of the business and to act as a corporate governance tool by which the users of the report may assess the performance of the company's managers in the fulfilment of their duties. In its Discussion Paper, the IASB defines management commentary as

information that accompanies financial statements as part of an entity's financial reporting. It explains the main trends and factors underlying the development, performance and position of the entity's business during the period covered by the financial statements. It also explains the main trends and factors that are likely to affect the entity's future development, performance and position. ${ }^{30}$

The Preface to International Financial Reporting Standards states that "other financial reporting" - such as management commentary - "comprises information provided outside financial

25 A Shipman, "Transatlantic strain still threatens global accounting standards", 29 October 2007, available at www.accountingweb.co.uk/cgi-bin/item.cgi? $\mathrm{id}=174918 \& \mathrm{~d}=1032 \& \mathrm{~h}=1024 \& \mathrm{f}=1026 \&$ dateformat $=\% 25 \mathrm{o} \% 20 \% 25 \mathrm{~B} \% 20 \% 25 \mathrm{Y}$ (last accessed 11 September 2008 ).

26 Ibid.

27 Ibid. See also S Thetford, "Global accounting harmonization: a challenging change" (2005) The Trusted Professional, at www.nysscpa.org/printversions/tp/405/article5.htm (last accessed 11 September 2008), noting that Sarbanes-Oxley has contributed significantly to the decrease in listings on the US markets due to the added costs of compliance. The result has been more listings in Europe and a greater use of IFRS.

28 Shipman, "Transatlantic strain", n. 25 above.

29 Willemain, "Corporate reporting", n. 16 above.

30 Discussion Paper, n. 2 above, para. 35. See also the definition provided by the Technical Committee of IOSCO: "The purpose of the MD\&A is to provide management's explanation of factors that have affected the company's financial condition and results of operations for the historical periods covered by the financial statements, and management's assessment of factors and trends which are anticipated to have a material effect on the company's financial condition and results of operations in the future. Companies should provide the information that is necessary for an investor's understanding of the company's financial condition, changes in financial condition and results of operations." 
statements to assist in the interpretation of a complete set of financial statements or improve users' ability to make efficient economic decisions". 31

The IASB identifies in its Discussion Paper a number of roles for management commentary. Management commentary comprises a narrative explanation of the company's business position that improves disclosure and transparency by supplementing the information given in the financial statements. The IASB expresses a preference for a management commentary that not only explains the performance, position and future prospects of the business but that also provides a fair review of the development of the business and its position by showing how the company has grown or changed in the current year and how it expects to grow or change in the future. The management commentary "supplements and complements financial information, providing insights into an entity's performance that financial statements cannot, and should not, be expected to achieve on their own". Management commentary also enables the company's management to review the actual performance of the business and the position it has achieved and to explain different outcomes from previous expectations. Investors may be informed about circumstances that may have affected the outcomes and to what extent strategies adopted by management achieved their objectives. Thus, through the management commentary the company's management is able to explain and provide a rationale for its current and future strategies and prospects. Management commentary is not to be seen as separate from the financial statements and nor should it be placed within them, but rather by accompanying and explaining the financial statements it should sit alongside them.

The IASB proposed in its Discussion Paper the introduction of a mandatory standard for a management commentary. This proposed standard would have taken into account the similarities and the differences of approach among the various jurisdictions considered. The objective of the management commentary set out in the proposed standard was to provide information to help investors: to interpret and assess the related financial statements in the context of the environment in which the entity operates; to assess what management views as the most important issues facing the entity and how it intends to manage those issues; and to assess the strategies adopted by the entity and the likelihood that those strategies will be successful.

The IASB makes clear that the management commentary should supplement and complement information in the financial statements and that it should provide an analysis through the eyes of management. It should have an orientation to the future and it should be understandable, relevant, supportable, balanced and comparable over time. The proposed standard would also have given guidance as to: the intended content of a management environment in which it operates; the business objectives and strategies in place to achieve them; key resources, risks and relationships that management believes may affect the entity's long-term value and how those key resources, risks and relationships are managed; financial and non-financial results and the extent to which the performance indicates future results and management's assessment of future prospects; and a description of performance measures and indicators used against the stated objectives. Within each of these areas listed the proposed standard would have given further detail about what should be included to meet the required coverage. The proposed standard was not to prescribe the form of the commentary, stating instead that this depends on the different businesses. Following responses to the Discussion Paper, the IASB has opted to develop a guidance document instead of a mandatory standard. The potential adoption problems among various jurisdictions persuaded the IASB that a non-compulsory guidance

31 Preface, n. 1 above, para. 7. 
document would be a more appropriate way forward with potential, in the longer term, to move on to creating a standard.

\section{Existing management commentary requirements in different jurisdictions}

The IASB's project is inspired by the fact that many jurisdictions recognise management commentary as an essential reporting document. In its Discussion Paper the IASB describes the rules in a number of jurisdictions including the UK. In the United States the Management Discussion and Analysis (MD\&A) is regarded as a regulatory matter by which the SEC has required listed companies to provide an MD\&A since 1968. The SEC considers that a numerical representation and brief accompanying footnotes alone may be insufficient for an investor to judge the quality of earnings and the likelihood that past performance is indicative of future performance and so an MD\&A allows managers to provide additional information necessary to understand a firm's financial condition, changes in financial condition and, results of operations. The SEC states that the MD\&A is "intended to give the investor an opportunity to look at the company through the eyes of management by providing both a short and long-term analysis of the business of the company". A similar definition is provided in Canada. The Canadian Securities Administrators issued new MD\&A requirements in National Instrument 51-102 Continuous Disclosure Obligations and described the MD\&A as "a narrative explanation, through the eyes of management, of how your company performed during the period covered by the financial statements, and of your company's financial condition and future prospects".

In Australia, the Corporate Law Economic Reform Program Act (CLERP) 2004 amended s. 299A of the Corporations Act to require expanded directors' reports. Thus, listed companies must provide information for members who would reasonably require to make an informed assessment of the operations of the entity, its financial position and its business strategies and prospects for future financial years. CLERP and the Australian Stock Exchange also make reference, for the purpose of legislative compliance, to the Group 100's Guide to the Review of Operations and Financial Condition. The guide states:

The Review should provide users with an understanding of the company by providing a short-term and long-term analysis of the business as seen through the eyes of the directors. This will be facilitated by providing useful financial and nonfinancial information and analysis ... A contemporary Review should include an analysis of industry-wide and company-specific and non-financial information that is relevant to an assessment of the company's performance and prospects.

New Zealand has no specific requirement for a management commentary but its financial reports generally have a wider scope and FRS-9 Information to be Disclosed in Financial Statements requires in a prospective report a comparison with actual performance.

The European Union has also legislated for the provision of management commentary. The Accounts Modernisation Directive amended the Fourth and Seventh Directives to require the annual report to

give an indication of any important events after the balance sheet date, the likely future development of the entity, the activities in the field of research and development, and the risks relating to the use of financial instruments including their management. 32

32 Directive 2003/51/EC of the European Parliament and of the Council of 18 June 2003 amending Directives 78/660/EEC, 83/349/EEC, 86/635/EEC and 91/674/EEC on the annual and consolidated accounts of certain types of companies, banks and other financial institutions and insurance undertakings, OJ L 178, 17/07/2003, pp. 16-22, Art. 46 Fourth Directive, and Art. 36 Seventh Directive. 
The Modernisation Directive requires the annual report to include "at least a fair review of the development and performance of the company's business and of its position, together with a description of the principal risks and uncertainties that it faces". The directive clarifies the requirement as

to the extent necessary for the understanding of the company's development, performance or position, the analysis shall include both financial and where appropriate, non-financial key performance indicators relevant to environmental and employee matters ... the annual report shall, where appropriate, include references to and additional explanations of the amounts reported in the annual accounts.

Germany has required a form of management commentary since 1931 and the requirements have been modified and developed over time. In 2004, a new GAS (German Accounting Standard) 15 Management Reporting was adopted, based on the EU legal requirements and taking into account requirements and practice in the US, Canada and the UK. Thus, in order to reduce the gap in information available to investors and managers, the group management report must present a fair review of the development of the business and of the group's position.

Expected developments shall be assessed and discussed together with the significant risks and opportunities ... Management reporting is intended as a vehicle for presenting information to users from management's perspective ... The focus should be on sustainable value creation ... The main factors which could influence changes in the value of the enterprise in the future should be disclosed and discussed ... It is recommended that the key performance indicators used internally to manage the group are quantified.

A more recent information document published by the IASB describes the jurisdictional requirements of thirteen additional countries ${ }^{33}$ and these range from having no regulation for narrative reporting ${ }^{34}$ to regulation of limited or moderate detail focused primarily on corporate governance ${ }^{35}$ or on accounting matters ${ }^{36}$ and, finally, to countries with detailed narrative reporting regulations. ${ }^{37}$

This part will be completed with a more detailed description of the UK requirements as not only has the UK's approach prior to the finalised regulatory requirements influenced the views of the IASB, but also in order to consider, as I set out to do in this paper, how the UK's requirements are likely to be affected by the IASB's project.

\section{THE UK'S BUSINESS REVIEW REQUIREMENTS INTRODUCED IN THE COMPANIES ACt 2006}

Prior to the introduction of the Companies Act 2006, there was in place a voluntary system for companies to produce an Operating and Financial Review (OFR) for which companies were guided by a Reporting Statement of best practice principles published by the Accounting Standards Board (ASB). All quoted and unquoted companies except for small companies were also required to include an enhanced business review under s. 234ZZB of the Companies Act 1985 and Sch. 7 of the same Act. During the discussions leading to the

33 IASB, "Information for observers, additional research re management commentary", related to Board Meeting of 24 July 2008, at www.iasb.org.

34 Albania, Nigeria and Uruguay, though Nigeria requires banks to report a strategy review to the central bank and in Uruguay publicly traded companies must inform the government of their economic and financial situation.

35 Philippines, Taiwan and Peru.

36 Pakistan, Brazil, Singapore and Hong Kong.

37 Turkey, Israel and Russia. 
reform of company law and the new Companies Act 2006 a major part of the reform agenda was the introduction of new requirements for a mandatory operating and financial review through which the Reporting Statement was to be turned into a Reporting Standard with detailed mandatory information requirements. It is those provisions and, in particular, the ASB's Reporting Statement, that have shaped the IASB's proposed standard. However, to the dismay of many stakeholders in the UK, Gordon Brown, who was then Chancellor of the Exchequer, announced in November 2005 that the rules for the OFR would be abolished. ${ }^{38}$ Following further consultations, new requirements were introduced that now form part of the Companies Act 2006.

The resulting provisions in the Companies Act $2006^{39}$ seek to streamline provisions for narrative reporting so that the requirements for quoted companies are more closely aligned to those for unquoted companies. Section 417 provides that unless the company is subject to the small companies' regime, the directors' report must contain a business review. ${ }^{40}$ The purpose of the business review is stated in s. 417 of the Companies Act 2006 to be "to inform shareholders of the company and help them assess how the directors have performed their duty under s. 172 (duty to promote the success of the company)". 41

Section 417, subs. (3), (4), (6) and (8) specify the contents required by all companies required to produce a business review. Subsection (5) provides further prescription for quoted companies and this subsection highlights more obviously the connection with the s. 172 duty. ${ }^{42}$

In s. 417, subs. (3) and (4) restate the earlier provision in s. 234ZZB:

(3) The business review must contain-

(a) a fair review of the company's business, and

(b) a description of the principal risks and uncertainties facing the company.

(4) The review required is a balanced and comprehensive analysis of -

(a) the development and performance of the company's business during the financial year, and

(b) the position of the company's business at the end of that year, consistent with the size and complexity of the business.

Subsections (6) and (8) also restate the earlier provisions relating to the content of the business review. Thus, subs. (6) specifies that the review

must, to the extent necessary for an understanding of the development, performance or position of the company's business, include-

(a) analysis using financial key performance indicators, and

(b) where appropriate, analysis using other key performance indicators, including information relating to environmental matters and employee matters.

38 For a description of the previous requirements and the discussions leading to reform of company law in the UK, see C Villiers, Corporate Reporting and Company Law (Cambridge: Cambridge UP 2006).

39 Note the insertion of new clauses in the Companies Bill, following extensive consultations: Department of Trade and Industry, "New clauses to keep company law reform 'light touch", 3 May 2006, at www.dti.gov.uk.

40 S. $417(1)$.

41 S. $417(2)$.

42 See below. 
According to the subsection, the term "key performance indicators" (KPIs) means factors by reference to which the development, performance or position of the company's business can be measured effectively.

Subsection (8) provides that the review must, where appropriate, include references to, and additional explanations of, amounts included in the company's annual accounts.

These provisions underline the importance of financial information - insofar as financial KPIs are compulsory and the business review is required, where appropriate, to link itself to and provide further explanation of the annual accounts. The other KPIs, including environmental and employee matters need only be included "where appropriate".

\section{Identifying common and distinct features across the jurisdictions}

The above brief overview of requirements among different jurisdictions shows that they have in common a clear aim for the management commentary. It is a document meant to enable users to understand the company's performance in a way that would not be possible if they were only supplied with the financial statements. The management commentary supplements and explains the information provided in the financial statements. Across all the jurisdictions described, the management commentary is also a tool that provides management with an opportunity to review and explain the company's performance and position and to consider and lay out to the users of the report the company's future prospects. In all the jurisdictions profiled here there are certain points of information that the commentary must contain. These are the main trends and factors affecting the company's current and future financial condition and performance. All jurisdictions surveyed highlight that the document should include a description of the company's business and the market in which it operates, the development and performance of the business and its financial performance and results, resources available to the business, and its assets, risks, performance measures and indicators and future prospects.

These similarities among the different jurisdictions suggest a possibility of convergence or a harmonisation of requirements. On the other hand, there are a number of features exhibiting important differences among the capital markets. For example, as has been noted above, the US favours a rules-based system whilst the UK is more principles-based in its approach. Some jurisdictions highlight the need for information about relationships with the company whilst others do not mention such relationships. Whilst many of the jurisdictions surveyed view the management commentary as a report that sets out an analysis of the business through the eyes of management, not all incorporate that requirement. ${ }^{43}$ Nor do all jurisdictions require future-oriented information. ${ }^{44}$ The IASB also identifies a further conceptual tension between management commentary and IFRSs because many jurisdictions include in their narrative reporting requirements information that is required within individual financial reporting standards and this is likely to lead to further discussion about placement of disclosures. ${ }^{45}$

The work of the IASB has significance for the future character of management commentaries and is likely to influence interpretation of the recently introduced requirements in the UK. A number of matters are particularly relevant, such as to what extent the management commentary requirements should be rules-based or principlesbased. The IASB's view is that non-financial disclosures are still in their infancy, particularly in relation to form and content, and they are still evolving internationally. On this basis the

43 IASB, "Information for observers", n. 33 above, para. 24.

44 Ibid.

45 Ibid., paras 25 and 26. 
IASB considers it premature and counterproductive to introduce detailed regulation at this stage. The IASB's current plan is to develop a guidance document that will outline best practice in formation and presentation of a management commentary. There are certain aspects that might be expected to be included within a management commentary but the form of their presentation and how detailed they should be remain open questions.

\section{Rules or principles?}

The IFRSs developed by the IASB have generally consisted of a principles-based approach rather than a rules-based approach. Various theoretical claims surround the preference by numerous regulators for a principles-based approach as opposed to a rules-based regime. Julia Black, moreover, points out the rhetoric of principles-based regulation: it provides a regulatory Utopia in which "regulation is targeted and focused, and preferably harmonized across jurisdictions, regulated firms are given the flexibility they need to get on with running their businesses, and consequently regulatory outcomes are achieved with no undue cost to business". 46 This Utopia is supported by many claims, for example, that they have been adopted and applied more flexibly across companies and countries. ${ }^{47}$ The principles-based approach also minimises, in theory, potential for conflict with existing laws and accounting practices and rules-based national standards have been able to coexist alongside the IFRS with the avoidance of political arguments about their effect on the national system. ${ }^{48}$ The principles-based approach has also encouraged the introduction of a guidance document for management commentary because it can more easily be relied upon to extend accounting principles beyond purely financial matters and into the general statements accompanying company reports without opposition from national standard-setters. ${ }^{49}$ According to Donnelly, this fact

means that the IASB's activity is likely to support the OECD's [Organization for Economic Co-operation and Development] strategy to promote transparency and qualitative information about corporate governance as part of financial reporting without raising concerns about firm demands on reporting standards that could become easily politicised. ${ }^{50}$

The principles-based approach then, appears to have provided a starting point from which a discussion on management commentary could be pursued. In the same vein, the IASB adopted the view in its Discussion Paper that a principles-based approach would be more appropriate than specifying the precise information to be disclosed within the management commentary or how it should be presented. Thus the favoured approach would be for the requirements to set out the principles, qualitative characteristics and essential areas necessary to make the information in the management commentary useful to investors.

The IASB identifies the main principle as the provision of information that assists in the interpretation of a complete set of financial statements or improves users' ability to make efficient economic decisions. In addition, the management commentary provides information that supplements the financial statements and explains the amounts reported in

46 J Black, Forms and Paradoxes of Principles Based Regulation, LSE Law, Society and Economy Working Paper 13/2008, at http://ssrn.com/abstract=1267722.

47 S Donnelly, "The International Accounting Standards Board” (2007) 12 New Political Economy 117, at 121.

48 Ibid.

49 Ibid., pp. 121-2.

50 Ibid., p. 122. See also R D Kershaw, “Evading Enron: taking principles too seriously in accounting regulation' (2005) 68 Modern Law Review 594, suggesting that the UK accounting regulators portrayed their approach as principles-based and thereby saved themselves from the political fallout which hit accounting regulation in the US in the wake of Enron's collapse, even though the accounting provisions in the UK and the US were almost identical: noted by Black, Forms and Paradoxes, n. 46 above, p. 11. 
the financial statements and the conditions and events that shaped that information in the financial statements. The information that complements, and therefore is not included in, the financial reports should include financial and non-financial information about the business and its performance. Another guiding principle is that the information that management deems important is also important to the users and, thus, the management commentary should provide an explanation of the company's financial statements that enables users to see the company through the eyes of management. The management commentary should also have an orientation to the future and thereby should help users to assess future prospects. The orientation to the future, according to the IASB, is about communicating through management's eyes, the direction the entity is taking, by, for example, setting out future strategies and goals. This principle does not require the management commentary to contain forecasts or predictions. In summary, the management commentary should be useful to its users and enable them to understand the financial statements through management's eyes and be able to assess the company's future prospects.

The downside of this principles-based approach, of course, is that it does not necessarily subject all companies to the same standard but, instead, is a flexible approach aiming to achieve compliance with the spirit, rather than the letter, of the law. This has its merits but, from the point of view of international standardisation, is unlikely to achieve that end. Moreover, some commentators identify a number of weaknesses in the principlesbased approach. Bratton, for example, suggests that whilst there is a lack of confidence in management incentives respecting accounting treatments and doubts about the level of auditor independence, "we have no actor plausibly positioned to make the delicate law-tofact determinations called for in a principles-base system". On this basis, Bratton argues that "accounting rules, with all their flaws, will continue to be the best choice in a secondbest world so long as they constrain managers and auditors most of the time". 51 Bratton predicts that the adoption of a principles-based approach would lead to a decrease in the level of reporting detail and an enhancement of comparability of treatment across different issuers. At the same time, there might occur a loss of transparency because the particulars in the economics of differing underlying transactions would be obscured. Furthermore, in order to operate effectively, a principles-based system requires professional auditors and lawyers who are empowered vis-à-vis their clients. In the US, that has not always been the case and so such professionals rely on the existence of rules in order to be able to say no to their clients. Currently, in the US, the regulated actors make the law-to-fact decisions, rather than judges empowered by the state. Those regulated actors rely on input from their auditors, who, unlike judges can only suggest no rather than say no absolutely. The auditors have little incentive to suggest no and thereby forego the rent they receive from an audit engagement. Bratton also notes that in other areas of commercial and business law there has been a shift towards more precise rules and away from broad standards. As he observes, 'business law and lawyers no longer subscribe to the legal realists' view that fact-specific adjudication under standards makes law more responsive". ${ }^{2}$ Furthermore, the movement towards rules has occurred partly because of a decline in confidence in judicial decisionmaking, partly because rules are perceived to offer more certainty than standards, and they appear to reduce risk for lawyers and their clients since a rule "imports a safe harbor and control of future events where a standard does not". Finally, Bratton suggests that a move towards a principles-based approach is not likely to increase transparency. On the contrary,

51 W W Bratton, "Enron, Sarbanes-Oxley and accounting: rules versus principles versus rents" (2003) 48 Villanova Law Review 1023, at 1037.

52 Ibid., p. 1050. 
since decision-making about treatments goes on in a black box, such decision-making evolves as a matter of practice amongst the insiders.

In the move towards international convergence, Bratton suggests that a principles-based approach is better suited to blockholding systems which are characterised by closer corporate governance monitoring from control shareholders in contrast with dispersed shareholder arrangements. ${ }^{53}$ Blockholders may intervene earlier and more cheaply in cases of management failure and they have greater ability to access information about operations. Additionally, blockholder systems usually involve longer shareholder time horizons which free management to invest for the long term and there will be less external pressures threatening insiders' control. This reduces incentives to manipulate numbers and thereby also frees the auditor to exercise judgment bound up in the application of a standard. Furthermore, according to Bratton, since the blockholder has direct access to corporate information, the numbers in the audited financial accounts are less significant. Auditors also have more reputational interests to lose in blockholding systems where they work for a closed club of top managers, large financial institutions and wealthy individuals who together can impose reputational sanctions more quickly than can dispersed shareholders. These observations indicate that the debate is not over on the essential cultural difference between the US and European accounting systems. Whilst the US appears to be letting go slowly of its rules-based approach, these difficulties identified by Bratton will have to be addressed. The Financial Services Authority (FSA) in the UK offers an interesting case study of the problems identified with a principles-based system. In particular, the principles-based approach requires effective discourse practices. As Black suggests, "regulatory conversations as to the meaning and application of the rules takes centre stage as their meaning and application is elaborated on in iterated communications between regulator and regulated". Whilst this approach, "both relies on and reinforces the image of the self-observing, responsible organization" 54 it also entails the maintenance of a costly communications network that may further trigger conditions of regulatory capture. ${ }^{55}$ The purposive objectives and outcome-oriented approach of the principles-based regulation relies on conversational elements but these require difficult, expensive networks and may involve varying interpretive communities. Some have suggested that the FSA takes a more pro-industry approach, willing to tolerate behaviour harmful to investors rather than scare off business through increased regulatory costs. ${ }^{56}$ Often, in reality, high-level principles are supplemented by a complex group of rules, guidance and other directives. Additionally, as Georgosouli observes, "the emphasis on high-level principles sometimes tends to tip the balance too much in favour of flexibility and at the expense of certainty and predictability". 57 Indeed, one might argue that these are contradictory objectives.

Whilst the debate about rules or principles appears likely to continue, the outlook as far as the management commentary is concerned is that it will at least start off with a principles-based approach. The main principle identified in the IASB's Discussion Paper is for the management commentary to enable users to interpret the financial accounts more effectively or to make efficient economic decisions. This provides a hint as to who are the intended users.

53 Bratton, "Enron", n. 51 above, p. 1054

54 Black, Forms and Paradoxes, n. 46 above, p. 9.

55 A Georgosouli, "The nature of the FSA policy of rule use: a critical overview" (2008) 28 Legal Studies 119-39, at 138.

56 J Robert Brown, "SEC v FSA: rules v principles" (2007) The Race to the Bottom: International governance, 23 July 2007, available at http://www.theracetothebottom.org/international-governance/sec-v-f (last accessed, 15 September 2008).

57 Georgosouli, "Nature of the FSA policy", n. 55 above, p. 138. 


\section{Who are the users?}

The UK's legal position and the view of the IASB is that the primary intended users are the shareholders. The IASB justifies this position by arguing that it provides consistency with the requirements relating to general financial reporting; that investors in public companies should be the primary focus. ${ }^{58}$ Although the range of information accompanying financial statements may be wide and might suggest that management views the scope of the management commentary and its intended audience also to be wide, ${ }^{59}$ the IASB maintains that those non-investor stakeholders should receive separate reports relevant to their specific interests and the management commentary should not be a replacement for those other reports such as sustainability and corporate social responsibility reports. ${ }^{60}$ Another problem identified by the IASB relating to non-shareholder recipients is that their needs or interests are less well defined or focused, ${ }^{61}$ which leads to potential problems for a management commentary, such as how long or how detailed it should be, and then there might also be a problem of lack of comparability.

Respondents to the Discussion Paper also follow this view. The ASB, moreover, expresses agreement with the principle that the focus should be on the needs of the same primary users, as defined in the current IASB Framework, who are the investors, but highlights a potential liability problem if the focus goes beyond current shareholders to include investors more generically, as was seen in the debates in the UK surrounding the OFR. ${ }^{62}$ In its response to the Discussion Paper, the ASB does not refer at all to other stakeholders. The Institute of Chartered Accountants in England and Wales (ICAEW) recognises that high quality management commentary will be of interest to a variety of users of financial statements. However, like the ASB, the ICAEW argues that the focus of management commentary should not extend beyond investors. In agreement with the IASB, the ICAEW argues that the more specific information needs of other stakeholders should be met through separate reporting processes, including corporate responsibility and sustainability reports. ${ }^{63}$ The ICAEW acknowledges that such issues may also be relevant to investors seeking to assess the financial performance and prospects of the reporting entity. ${ }^{64}$ It further notes that if the potential legal duty of care for directors extends beyond members as a body to all investors, including prospective investors, that would lead to "anodyne disclosures and a rigid approach by boards to management commentary". ${ }^{65}$

With regard to the issue of relevant users, those in the stakeholders' camp will be disappointed by the apparent outcome of the UK business review legislation as well as the general consensus response to the IASB's Discussion Paper. When various stakeholder groups were involved in the debates about the business review legislation, the possibility of a broader user pool was apparent. Indeed, in a response to the White Paper Modernizing Company Law, the Government stated that the OFR would

\footnotetext{
58 Discussion Paper, n. 2 above, para. 25.

59 Ibid., para. 26.

60 Ibid., para. 30.

61 Ibid., para. 29.

62 ASB, "Letter to Alan Teixera, of IASB, commenting on the discussion paper", 9 February 2006, at www.iasb.org, Appendix, response to question 4 of the discussion paper.

63 ICAEW, "Management commentary - memorandum of comment submitted in April 2006 in response to the IASB discussion paper 'Management commentary', published in October 2005", at http://www.icaew.co.uk, para. 16.

64 Ibid.

65 Ibid., para. 17.
} 
be of benefit not only to shareholders and potential investors in companies, but also to all those concerned with wider aspects of company behaviour, whether as employees, local residents, or as interest groups involved in environmental/social issues or general corporate governance. ${ }^{66}$

However, s. 417 of the Companies Act 2006 states that the purpose of the business review is "to inform shareholders of the company and help them assess how the directors have performed their duty under section 172 (duty to promote the success of the company)". 67 In this way shareholders collectively may exercise their governance rights more effectively. Lord Sainsbury stressed in the House of Lords that the business review "is not designed to help individuals decide on investment decisions, nor is it targeted at the wider public in the sense that they should be entitled to rely on it, although they may well read it". ${ }^{68}$ The UK's position is to limit the obligations relating to the business review to the shareholders collectively. Others will not be denied access to the document, but their right to rely on the information reported will not be legally supported.

Shareholders, as capital providers, clearly enjoy a privileged status over other stakeholders as recipients of financial statements and other related reports. In their jointly issued Exposure Draft for improving the Conceptual Framework for Financial Reporting, the FASB and the IASB state that present and potential capital providers have the most critical and immediate need for the information in financial reports. Whilst the two boards recognise that other potential users of financial reports also have an interest in making similar assessments to those of the capital providers, they conclude that

because present and potential capital providers have the most direct and immediate interest in an entity's ability to generate cash inflows and management's ability to protect and enhance capital providers' investments, the Boards decided to designate them as the primary users of financial reporting information. ${ }^{69}$

It might be possible to respond to the potential disappointment of stakeholders by using two of the points made in the joint Exposure Draft. First, that without a defined group of primary users, the management commentary would risk becoming unduly abstract or vague. Thus, an identified group of primary users would give the management commentary an important focus. ${ }^{70}$ Secondly, as is stated in the existing Framework, "As investors are providers of risk capital to the entity, the provision of financial statements that meet their needs will also meet most of the needs of other users that financial statements can satisfy." 71 The same argument could be made for the management commentary. Indeed, it could be argued that the views and interests of shareholders, current and potential, may be undergoing change as a result of increased awareness of the relevance of issues such as sustainability and corporate social responsibility. Shareholders are increasingly likely to desire such information as much as other stakeholders. Indeed, an investment analyst is reported to have stated recently: "We might not be particularly interested in every specific issue mentioned in a CSR [corporate social responsibility] report. But the presence of good CSR reporting tells us there is good CSR management. And that tells us the company as a

66 Sixth Report of Session 2002-03, HC 439, para. 69.

67 S. 417(2), emphasis added.

68 Lords Hansard, 10 May 2006, col. 920.

69 FASB and IASB, Exposure Draft, Conceptual Framework for Financial Reporting: The objective of financial reporting and the qualitative characteristics and constraints of decision - useful financial reporting information, No. 1570-100, 29 May 2008, at para. BC1.19.

70 Ibid., para. BC1.18.

71 IASB, Framework For Financial Reporting, para. 10. 
whole is well-managed." 72 In response to that statement the group Tomorrow's Company remarked: "Viewed in this light, the quality of the annual report becomes a proxy for the quality of the management team." 73 One company was also reported as stating that "This year was different in that we have moved away from a distinct CSR report or section because it has become so embedded in what we do."74

The relevance of environmental, social and governance issues for investment decisions is increasingly recognised because of the "body of creditable evidence demonstrating that such considerations often have a role to play in the proper analysis of investment value". ${ }^{75}$ Not only is there a growing popularity in "socially responsible investing" but integrating environmental, social and governance considerations into an investment analysis is likely to obtain more reliable predictions of financial performance. ${ }^{76}$ Shareholder value today is not limited to short-term profit. In the UK, the legal embrace of the term "enlightened shareholder value", arguably widens the shareholders' interests and in so doing offers some support for the interests of other stakeholders. The extension of the directors' duty in promoting the success of the company to take into account the interests of other stakeholder groups forces a departure from exclusively looking after the shareholders and "has significant implications for the transformation of external company reporting beyond the financials of the annual accounts and reports". ${ }^{77}$ In this light, accounting is more likely to "be regarded as a social practice rather than a purely technical matter of getting the numbers right". ${ }^{78}$

The IASB states in its Discussion Paper that other interest groups should receive separate reports to address their needs and that these should not be replaced by the management commentary. A justification for this suggestion is that if the management commentary were to cover all interests it would be too abstract and potentially too large so that the information sought is effectively obscured. Separate, more specific and direct reports ought to avoid that problem and, ideally, the management commentary should make cross-reference to those other reports as well as to the financial statements. Contrary to these arguments is the fact that, whilst in some jurisdictions such a practice may well arise, currently in the UK detailed social and environmental reports are still largely a matter of voluntary reporting ${ }^{79}$ and the business review requirements stop short of guaranteeing the provision of such information, leaving it as a matter of decision by the directors if they consider it necessary for an understanding of the business.

72 "Corporate responsibility reporting - ethics, profits and materiality", Radley Yeldar seminar, London, 15 November 2006, quoted in Tomorrow's Company, The Future of Corporate Reporting - State of play - February 2007, at www.tomorrowscompany.com, p. 14.

73 Tomorrow's Company, The Future, n. 72 above, p. 14.

74 Ibid., p. 13.

75 United Nations Environment Programme Finance Initiative (UNEP FI) Asset Management Working Group, A Legal Framework for the Integration of Environmental, Social and Governance Issues into Institutional Investment (2005), pp. 10-11: cited by B Horrigan, "21st century corporate social responsibility trends - an emerging comparative body of law and regulation on corporate responsibility, governance and sustainability" (2007) 4 MqJBL 85, at 108-9.

76 UNEP FI, Legal Framework, n. 75 above, p. 13.

77 Y Chahed, (Summer 2007) (13) Risk and Regulation (CARR Newsletter).

78 Ibid

79 There are some discrete legislative provisions requiring information of this nature to be published such as can be found in s. 35 of the Pensions Act 1995 which requires pensions trustees to develop and act according to a statement of investment principles that records their policy on how they will exercise their voting rights and must "identify the extent (if at all) to which social, environmental or ethical considerations are taken into account in the selection, retention and realization of investments". 
It seems likely that debate will continue about who are the relevant users for the management commentary. It is clear that a wide range of constituents are interested in "accounting issues" as a matter for public regulation. There is also likely to occur "a renegotiation of the boundaries between what accounting reports 'can' and 'should' do as competing groups define and advance their interests under the umbrella of 'accounting' as part of the legislative process". ${ }^{80}$ In this light, the IASB may be required to offer a clearer justification for its investor focus. Not only does the IASB itself acknowledge a lack of empirical research on user needs, but also, as Collins et al. suggest, "significant value judgements of a political nature are involved ... and this justification merely appears to reiterate traditional beliefs about the hierarchy of user needs". ${ }^{81}$ Arguably, there is a possibility of change, but it seems unlikely in the near future. Instead, what can be concluded, is that the current focus on investor interests in the management commentary project merely deepens the narrow shareholder-centred orientation for corporate law. The IASB in this way contributes to a further convergence towards Anglo-American capitalism and system of corporate law and governance. ${ }^{82}$

\section{Management to determine content of the management commentary}

Aligned to the principles-based approach to management commentary, the IASB's Discussion Paper indicates that management should determine which information to include within the management commentary. As the IASB states,

specifying disclosures for MC is more difficult than for information included in financial statements. The types of activities that are critical to an entity will be specific to that entity. As a consequence regulators have tended to identify the key elements that reflect the type of content they expect to see in MC rather than defining the elements themselves. Specifying a detailed list also encourages a "tick box" mentality, which should be avoided. ${ }^{83}$

Similarly, the IASB argues that management should also decide the best way to present the content.

In our view, providing flexibility in both the presentation and content of $\mathrm{MC}$, and using guidance to demonstrate that there are many ways to achieve the objective of MC, reduces the risk that preparers will use standard bland language, repeated year after year. ${ }^{84}$

The IASB states that it was influenced by the ASB's original proposed Reporting Standard 1, since it provided a helpful structure. Thus, the main elements to be contained within the management commentary in the opinion of the IASB include the nature of the business, the entity's objectives and strategies, its key resources, risks and relationships, its results and prospects, and its performance measures and indicators. Section 417(5) of the Companies Act 2006 gives to quoted companies more specific direction on the contents to be included in the business review though they only have to provide such details to the extent that they consider is necessary for an understanding of the development, performance or position of the company's business. The information identified is closely linked to the matters that directors must consider in the duty to promote the success of the company in s.172 of the Companies Act 2006. None of the specified matters to be included

80 Chahed, Risk and Regulaion, n. 77 above.

81 W Collins, I Fraser and J Stevenson, Response to LASB Discussion Paper on Management Commentary, at www.iasb.org, at p. 3.

82 See Gallhofer and Haslam, "Exploring”, n. 24 above, pp. 643-4.

83 Discussion Paper, n. 2 above, para. 97.

84 Ibid., para. 98. 
are in fact compulsory, but, if they are not covered, the business review must state that fact. The subsection does not require an explanation why such matters are not covered but, arguably, the investors might expect an explanation if the business review is to be seen as a credible and worthwhile document.

The subsection is vague on the points it identifies for coverage and so what is to be included is left very open. So long as the information given can be considered to help in understanding the company's business development, performance or position then the directors may determine for themselves what information is provided. Such matters need only be included if necessary for an understanding of the business. The section gives no hint about what degree of understanding is needed or how directors should decide to what extent such matters are necessary to this understanding of the business. The directors are given power to decide not to disclose information relating to matters under negotiation, approaching developments or persons with whom the business has a relationship, if they consider that disclosure of such information would be seriously prejudicial to the company's interests or to the third person's and the public interests. ${ }^{85}$ KPMG states that it is for companies to "select those KPIs that will succinctly demonstrate to members the development, performance and position of the business"; seeking additional assurance for KPIs might protect the company from inconsistent calculations; the KPIs used should be what the board is already monitoring and they should be aligned to strategies, objectives and risks; the most relevant KPIs are likely to be reviewed at each board meeting; and there will usually be five or six relevant KPIs. ${ }^{86}$

The IASB concluded that any IASB standard or guidance on management commentary should not specify the performance measures or indicators that entities should disclose. The IASB adopts the view that the ASB's approach reflects the principle that the management commentary should be through the eyes of management and so "the onus is on management to determine which performance measures and indicators, and how many, reflect best what is required for an understanding of the business".

The effect of this managerial discretion within the IASB and UK approaches, together with their principles-based approach, is likely to result in a lack of comparability among reports, arguably because the provisions are too broad and vague. Alternatively, over time a degree of consensus may develop about what might be expected. The IASB indicates that future guidance is likely to be required to provide more definitive guidance to standardise various non-IFRS financial performance measures and other non-financial performance measures and indicators. One reason for defining measures used is to facilitate comparison between entities and greater consistency in reporting by those entities that regard each measure as important. Yet, this might result in an impression of uniformity as boards

85 Subs. (10) and (11).

86 Smith \& Williamson Solomon Hare highlight possible examples. Financial KPIs might include: gross profit margins; net operating margin; return on capital employed; gearing/interest cover; sales growth; sales per employee; sales per square foot; operating cash flow; liquid asset ratio; hire income as a percentage of fleet cost. The following are possible non-financial KPIs: market share; number of subscribers; customer retention; new business from existing customer referrals; environmental spillage; waste disposal; $\mathrm{CO}_{2}$ emissions; employee health and safety; accident statistics; staff satisfaction levels; staff retention levels; efficiency (complaints as percentage of total output). KPMG makes a number of suggestions in its publication relating to scene-setting; objectives of the company; strategy; risks and uncertainties; measurement; performance; and forward-looking information. Apart from these broad contents, KPMG also suggests that the business review should contain the following features: that it reflects the directors' viewpoint; that it provides matters of relevance to the members; that it provides forward-looking information; that it complements and supplements the financial statements; that it is comprehensive and understandable; that it is balanced and neutral; and that it is comparable over time: KPMG, The Directors' Report and the Business Review (London: KPMG LLP 2006), at www.kpmg.co.uk/pubs/302810.pdf (last accessed 15 September 2008). 
adhere strictly to the guidelines issued by bodies such as the ASB or of large accounting firms such as KPMG. ${ }^{87}$ This would not then be very different from the box-ticking culture that these measures in fact aim to avoid. A further restriction may emerge from directors' potential liability for the information they publish.

\section{Potential liabilities of directors arising from the management commentary}

The management commentary, as a corporate governance report, has the objective of enabling shareholders to assess how well the directors have performed in their duty to promote the success of the business. One of the main challenges in the development of management commentary containing forward-looking information is the issue of potential liability. The shareholders might be able to challenge the directors on the basis of the information disclosed in the management commentary, not only with regard to their duty to promote the success of the company but also for inaccurate information.

In its Discussion Paper, the IASB notes that the regulatory or legal environment influences how and the extent to which management commentary is oriented towards the future. The IASB also observes that in some jurisdictions there are safe-harbour provisions to restrict liability claims or regulatory provisions, or both, that require cautionary statements relating to forward-looking information. ${ }^{88}$ The IASB does not express a preference for any particular liability regime. In the UK, the Companies Act 2006 has clarified the position with regard to liability for false or misleading statements in reports in s. 463. These provisions impose on directors liability for statements in the directors' report, directors' remuneration report and any summary financial statement derived from those reports which are untrue or misleading and are made with the knowledge that they are untrue or misleading or the director was reckless as to whether they are untrue or misleading. Similarly, a director will be liable for omissions which he or she knows to be dishonest concealment of a material fact. In such circumstances, the director is liable to compensate the company for losses suffered as a result of relying on the report. Directors will not be liable for statements made in good faith, even if they turn out to be untrue or misleading. Under the legislation, issuers will be liable to an individual investor or other third party only if that party has reasonably relied on the statement for investment purposes, and suffered loss as a result of the statement or omission. The UK provisions restrict directors' liability not only in relation to forward-looking statements but also in relation to statements made in narrative reports generally.

Although the IASB does not directly make the connection, a related point of view that it expresses is that all the information contained within management commentary is supportable, ${ }^{89}$ and where there is uncertainty the management commentary should contain a cautionary note to ensure that users are made aware of such areas of uncertainty, in particular with forward-looking information. ${ }^{90}$

\section{Current reporting practice in the UK and implications for the IASB's project}

The existence of a regulatory framework on management commentary reports is likely to give rise to greater amounts of disclosure by companies compared with companies

87 Already in the UK the appearance of uniformity has been observed: Deloitte Touche, Written to Order: Surveying OFRs, EBRs and narrative reporting in annual reports (2007), at www.deloitte.co.uk.

89 Ibid., para. 75.

90 Ibid., para. 76. 
following voluntary guidelines applying to such reports. ${ }^{91}$ This observation suggests that if the IASB's project results in a reporting standard among the IFRS this will generate publication of more company information to investors.

In the UK, Pricewaterhouse Coopers suggests that the introduction of the enhanced business review requirements has brought about improved communication of strategic priorities, KPIs and risk. ${ }^{92}$ They note, similarly with Yun Seah and Tarca, that the scope and nature of information disclosed have improved, but there remains room for improvement in the quality of information reported. The legislation that currently exists in the UK is new and so there is still time for new reporting practices to be established. In addition, its highlevel nature leaves room for different interpretations to be made. The Reporting Statement of Best Practice acts as a guide, but this does not have to be followed. Without alternative guidance to the legislation, however, it seems likely that, increasingly, companies will rely on the Reporting Statement as the basis for shaping and developing their narrative reports. As time goes on, assessments by professional bodies and practitioners may also develop a basis for measuring compliance with the legislation, but at this early stage the line between compliance and good practice is not clearly drawn. Nor, indeed, is the line between compliance and non-compliance with the legislation. There are indications that large companies are taking their responsibilities seriously. The new requirements have resulted in a general lengthening of annual reports and there is emerging an appearance of uniformity. On the other hand there are variations in the number and types of KPIs described.

The IASB looks set to continue its work on the management commentary and initial signs suggest that a guidance document will be developed with a principles-based approach. The IASB's project will probably not make a huge difference to practice being developed in the UK other than to consolidate what has been achieved so far. By and large, the broad principles identified by the IASB match those of the UK and both the IASB and the UK identify the same primary users, both support managerial discretion and both advocate publication of future-oriented information. However, for the IASB's project more broadly, the prospects of success in achieving comparability and international convergence are more open to question. This leads me to some more general conclusions.

\section{Conclusions}

A number of general conclusions can be offered. First the prospects of achieving an international standardisation of provisions for management commentary are open to debate. Although there are many similarities in approach and principles among many of the jurisdictions examined by the IASB in its research on management commentary, still there are significant differences between the arrangements in those jurisdictions. Some jurisdictions do not require any form of management commentary. Thus, to introduce new rules to those jurisdictions will potentially meet with political and cost barriers. Even if a general formal standard were adopted, especially if presented in the form of general principles, the different interpretations and forms of implementation likely would be a major obstacle to achieving a standardised practice internationally. Zeff reminds us that the obstacles to achieving convergence include problems of interpretation, language and

91 S Shi Yun Seah and A Tarca, "The impact of regulatory framework on management commentary reports", Working Paper, Version 28, February 2007, available on ssrn papers network Scholar, http://papers.ssrn.com/sol3/papers.cfm?abstract_id=962628 (last accessed 15 September 2008).

92 Pricewaterhouse Coopers LLP, Show Me More than the Money - An assessment of how prepared companies are for the business review (London: Pricewaterhouse Coopers LLP 2006) and Pricewaterhouse Coopers LLP, Business Review: Has it made a difference - a survey of the narrative reporting practices of the FTSE 350 (London: Pricewaterhouse Coopers LLP 2007). 
terminology. ${ }^{93}$ These are formidable hurdles to a genuine international convergence of regulatory arrangements or corporate practice. In any event, the depth of international convergence also remains debateable.

Not only do episodes such as the European carve-out of certain IFRSs, such as IAS 39, put into doubt the sincerity of the push towards convergence, but cultural differences and continuing competition for capital investments encourage continuation of a degree of regional protectionism. The American stance, indeed, gives rise to those suspicions. The supposed relaxation of the US insistence on rules-based accounting regulation in the wake of Enron hardly rings true when the key regulatory response to Enron was the introduction of the Sarbanes-Oxley Act which was characterised strongly by rigid rulesbased requirements. The apparent change of heart was almost certainly a response to the threat of companies de-listing from US stock markets ${ }^{94}$ rather than a rejection of the rules-based approach to regulation.

The IASB has been accused of having over-simplified its work in the past and at this stage its contribution to the debate on management commentary is also basic and superficial. In the UK, debates over the OFR were long, heated and complex. This was demonstrated by the withering response to the Chancellor's announcement to scrap rules for the OFR towards the end of 2005, in which he attempted to offer to the business community a reprieve from regulatory burdens. Many in the business community actually sought some form of business review requirement and the EU legislation had already laid the foundation for enhanced narrative reporting. Another aspect of the complexity within the business review requirement was that related to potential liability and, again, this was debated heatedly in the UK. Yet the IASB offers no way forward on this point in its Discussion Paper.

The narrow version of capitalism that the IASB's proposed management commentary supports, in particular, an investor-centric view of the company, may well encourage the US regulators to go along with it. What makes the IASB's work on the management commentary potentially more palatable in the more immediate future is its principles-based stance since this, as noted above, allows for a degree of flexibility. Yet the problems of uncertainty and possible limitations to investor protection this stance may entail will also have to be faced.

The UK's experience relating to business review requirements is so far relatively positive. However, these are still early days and more research into the reporting practices of companies and how those reports are received and used by their recipients is essential. Longer reports do not guarantee better quality. Effective communication requires a true and potentially costly dialogue that risks regulatory capture. The real test on the effectiveness of the communication is to be measured by the companies' results and their investor relations. The IASB should follow the UK's experience closely as this may have lessons for the international business community. In turn the input of other jurisdictions and debates in the IASB may also inform how our legislation is to be utilised and potentially altered. At the very least, the IASB's work is likely to give greater impetus to the work of organisations such as the enhanced business reporting consortium, ${ }^{95}$ which has been developing an enhanced business reporting framework.

93 S A Zeff, "Some obstacles to global financial reporting comparability and convergence at a high level of quality” (2007) 39 British Accounting Review 290-302.

94 See further, A Bhimani, "The role of a crisis in reshaping the role of accounting" (2008) 27 Journal of Accounting and Public Policy 444-54.

95 www.ebr360.org. 
Management commentary is firmly recognised as an essential aspect of corporate governance. How it is to be developed internationally though is still to be settled and the only prediction that can be made with any certainty is that the debate will be long and complex. 